\title{
Inheritance of allozymes and hybridization in two European Tilia species
}

\author{
M Fromm and HH Hattemer \\ Institut für Forstgenetik und Forstpflanzenzüchtung, Universität Göttingen, Büsgenweg 2, D-37077 Göttingen, Germany
}

\begin{abstract}
Inheritance analysis of seven enzyme systems in hexaploid Tilia cordata Mill. was performed utilizing single trees and their open-pollinated progenies. Genetic analyses of 12 polymorphic gene loci showed that $T$. cordata had disomic inheritance despite being an allopolyploid. T. platyphyllos Scop. was also used in the investigations although no genetic inheritance analysis was carried out. In comparison
\end{abstract}

Keywords: T. cordata; T. platyphyllos; T. × europaea hybrids; gene markers; allozymes; inheritance

\section{Introduction}

Few investigations of allozyme gene loci have been carried out in Tilia. cordata (Maurer and Tabel, 1995) and no inheritance analyses have been undertaken. Thus, the first step towards an analysis of its reproduction system was the development of electrophoretic methods, the clarification of allozyme inheritance in hexaploid T. cordata and the identification of polymorphic allozyme gene markers.

In regions where both $T$. cordata $(2 n=6 \times=82)$ and T. platyphyllos $(2 n=6 \times=82)$ occur sympatrically, spontaneous hybridization occurs (Keiper, 1916; Pigott, 1991). The pendulous inflorescence of $T$. platyphyllos is a dominant trait, and the inflorescences of pure T. cordata are erect (Pigott, 1991). A further distinguishing trait between the two species is the reddish-brown stellate hairs in the vein-axils on the underside of $T$. cordata leaves (Pigott, 1991). The hybrids between the two species show degrees of intermediacy for most other traits (Pigott, 1991); it is often not possible to differentiate between $T$. cordata, $T$. platyphyllos and their hybrid $(T . \times$ europaea $)$ on the basis of morphological traits, especially in winter when the trees do not bear fruits (Scheller, 1972). Thus markers that discriminate between the species are also reported in this paper.

\section{Material and methods}

\section{Material}

A total of 138 dominant or codominant T. cordata and three T. cordata $\times T$. platyphyllos hybrids grow in a 40 ha mixed forest near Schwiegershausen $\left(10^{\circ} 11^{\prime} 25^{\prime \prime} \mathrm{E}, 51^{\circ}\right.$ $40^{\prime} 45^{\prime \prime} \mathrm{N}$ ), a small village west of the Harz Mountains; with $T$. cordata, zymograms of 10 spontaneous $T$. cordata $\times T$. platyphyllos hybrids showed markedly different banding patterns with species-specific alleles at 13 of the 14 described gene loci. Hence, differentiation between both species and their naturally occurring hybrid $(T . \times$ europaea) is easily feasible with allozyme studies.

Heredity (2003) 91, 337-344. doi:10.1038/sj.hdy.6800325 the dominant species is Fagus sylvatica. The forest is surrounded by extensive agricultural land and may, therefore, be regarded as more or less isolated from other forests. For inheritance analysis, buds and more than 3700 seeds from 49 T. cordata were collected in the 1995 full mast year and investigated genetically. Additionally, buds of 91 T. cordata, 67 T. platyphyllos and seven hybrid individuals from other parts of Germany were used to identify species-specific alleles (Table 1). All trees were more than 120 years old.

The fruits were stored at $-20^{\circ} \mathrm{C}$. In winter, branches were cut from the trees and kept in climate chambers at $20^{\circ} \mathrm{C}$ until bud burst and leaves from the bursting buds were used for electrophoresis.

\section{Electrophoretic methods}

\section{Extraction of enzymes}

Leaf and bud tissues were homogenized in approximately $100 \mu \mathrm{l}$ extraction buffer $(97 \mathrm{mg}$ Tris $\mathrm{pH} 7.5,1 \mathrm{~g}$ saccharose, $300 \mathrm{mg}$ PVP, $15 \mathrm{mg} \mathrm{Na}{ }_{2}$ EDTA, $10 \mathrm{mg}$ BSA and $30 \mathrm{mg}$ DTT dissolved in $10 \mathrm{ml}$ distilled water). For binding phenols and heavy metals, approximately $2 \mathrm{mg}$ Polyclar was added to the extraction buffer before homogenizing the samples; addition of $\beta$-mercaptoethanol shows only a slight improvement in activity and the clarity of banding patterns for a few enzyme systems.

\section{Separation and staining of enzymes}

In order to investigate a large number of samples, a compromise was made between optimal results and the cost and effort, for example, for some gene loci involved (Table 2) better results were attained, although there was no significant improvement in the interpretation of the loci but a reduction in practicability. Recipes for enzyme staining were modified according to Maurer and Tabel (1995; details in Fromm (2001)); substrate specificity of the enzymes was tested for all gene loci. 


\section{Genetic analysis}

As no controlled crosses were carried out, the inheritance analysis method of Gillet and Hattemer (1989) was applied. This method has been used successfully for tree species, including Castanea sativa (Fineschi et al, 1989), Cupressus sempervirens L. (Papageorgiou et al, 1993), Alnus acuminata (Murillo and Hattemer, 1997), Acer campestre (Leinemann and Bendixen, 1999) and Acer pseudoplatanus (Konnert et al, 2001). This method allows one to test the "one gene-one gene marker hypothesis" and of codominant inheritance on the basis of open-pollinated progenies of known seed trees.

Under the assumption of regular meiotic segregation and random fertilization of ovules, as well as the absence of viability selection, the following quantitative and qualitative relations in the investigated progenies must be found:

In the case of a homozygous seed tree (eg $A_{i} A_{i}$ ):

(a) All progeny must possess the allele of the maternal tree $\left(A_{i}\right)$.

In the case of a heterozygous seed tree (eg $A_{i} A_{j}, i \neq j$ ):

(b) Each individual among the offspring must contain one of the maternal alleles, $A_{i}$ or $A_{j}$.

(c) The number, $N_{i j}$, of heterozygous progenies, $A_{i} A_{j}$, is expected to be equal to the sum of the $N_{i i}+N_{i j}$ homozygous progenies, $A_{i} A_{i}$ and $A_{j} A_{j}$, that is, $\left[N_{i j}=N_{i i}+N_{i j}\right]$.

(d) The number, $N_{i k}$, of the heterozygous progenies, $A_{i} A_{k}$, is expected to be equal to the number of the heterozygous progeny, $A_{j} A_{k}$, that is, $\left[N_{i k}=N_{j k}(k \neq i, j)\right]$.

Table 1 Material collected in the Schwiegershausen population for genetic analyses and in southern Germany for species distinction

\begin{tabular}{lccc}
\hline & \multicolumn{3}{c}{ Number of sampled trees } \\
\cline { 2 - 4 } & T. cordata & T. $\times$ europaea & T. platyphyllos \\
\hline Schwiegershausen & $\begin{array}{c}138 \text { and fruits } \\
\text { of } 49 \text { trees } \\
91\end{array}$ & 3 \\
$\begin{array}{l}\text { Southern Germany } \\
\text { (Bavaria, Baden-Wurttemberg and Rhineland-Palatinate) }\end{array}$
\end{tabular}

If statistical tests show a significant deviation between observed and expected frequencies, at least one of the above-mentioned relations or assumptions is violated and the gene locus concerned is unsuitable as a gene marker. If no significant deviation is detected, the gene locus can be regarded as a gene marker. However, it is possible that significant deviations can have methodological causes (eg sampling, data input).

Deviations between observed and expected frequencies were tested with $\chi^{2}$ goodness-of-fit tests. Their results are presented in Tables 3-6 in terms of probabilities of greater values of $\chi^{2}$.

A value of 1.00 means that the observed and expected frequencies are in complete agreement, below 0.05 deviations are significant.

\section{Results}

For the enzyme system 6-PGDH (EC 1.1.1.44), two or more overlapping zones were found and, therefore, no interpretation of these complex banding patterns was possible. For the enzyme system ACO (EC 4.2.1.3), clear results were obtained for leaf material, but in seeds enzyme activities were too weak for routine investigation. For enzyme systems EST (EC 3.1.1.1), GDH (EC 1.4.1.3.), G-6-PGDH (EC 1.1.1.49), NDH (EC 1.6.99.3) and SAP (EC 3.1.3.2), only weak and/or blurred patterns were obtained and no analysis was carried out. No IDH (EC 1.1.1.42) variation was detected in $T$. cordata, although variation was found in T. platyphyllos. Inheritance analysis was performed for gene loci coding for the following enzyme systems: AP (EC 3.4.11.1), FDH (EC 1.2.1.2), $\mathrm{MDH}$ (EC 1.1.1.37), MNR (EC 1.6.99.2), PGI (EC 5.3.1.9), PGM (EC 2.7.5.1) and SKDH (EC 1.1.1.25).

\section{AP - aminopeptidase}

Four zones of activity stain for the monomeric enzyme system AP using both leucine and alanine. Zones $A p-A$ and $A p-C$ usually show only faint activity, therefore their analysis was abandoned. Ashton and Braden's (1961) separation system was preferred for the analysis of locus $A p-B$, while with the histidine-citrate system better separation of the enzyme variants was achieved. However, in the latter system cobands appeared at locus $A p-B$,

Table 2 Separation systems for starch gel electrophoresis of Tilia allozymes. Running coniditons valid for $27 \times 11 \mathrm{~cm}$ gels

\begin{tabular}{|c|c|c|c|c|c|}
\hline \multirow[t]{2}{*}{ Buffer system/electrode buffer } & \multirow[t]{2}{*}{ Composition of gels } & \multicolumn{3}{|c|}{ Running conditions } & \multirow[t]{2}{*}{ Enzyme system } \\
\hline & & I const. & U var. & Time & \\
\hline \multicolumn{6}{|l|}{ Ashton system 8.1} \\
\hline \multirow[t]{4}{*}{$0.03 \mathrm{M} \mathrm{LiOH} / 0.2 \mathrm{M} \mathrm{H}_{3} \mathrm{BO}_{3}$} & $\begin{array}{l}0.05 \mathrm{M} \text { Tris-citrate } \mathrm{pH} 8.1 \\
\text { plus } 10 \% \text { electrode buffer }\end{array}$ & $40 \mathrm{~mA}$ & \multirow{4}{*}{$\begin{array}{l}\max .500 \mathrm{~V} \\
\text { or } \\
\max .500 \mathrm{~V}\end{array}$} & $17 \mathrm{~h}$ & \multirow{4}{*}{$\begin{array}{l}\text { FDH } \\
\text { AP } \\
\text { PGM } \\
\text { PGI }\end{array}$} \\
\hline & $10 \%$ starch & $80 \mathrm{~mA}$ & & $6 \mathrm{~h}$ & \\
\hline & $1 \%$ urea & & & & \\
\hline & $0.07 \% \mathrm{Na}_{2} \mathrm{EDTA}$ & & & & \\
\hline \multicolumn{6}{|l|}{ Histidine-citrate system pH 6.2} \\
\hline \multirow[t]{4}{*}{ 0.06 M Histidine-citrate } & $\begin{array}{l}\text { Electrode buffer plus } 75 \% \text { dist. } \mathrm{H}_{2} \mathrm{O} \\
10.5 \% \text { starch }\end{array}$ & $40 \mathrm{~mA}$ & \multirow{4}{*}{$\begin{array}{l}\max .250 \mathrm{~V} \\
\text { or } \\
\max .250 \mathrm{~V}\end{array}$} & $17 \mathrm{~h}$ & \multirow{4}{*}{$\begin{array}{l}\text { AP } \\
\text { MDH } \\
\text { MNR } \\
\text { SKDH } \\
\text { (IDH/ACO) }^{a}\end{array}$} \\
\hline & $2 \%$ sucrose & $80 \mathrm{~mA}$ & & $6 \mathrm{~h}$ & \\
\hline & $1 \%$ urea & & & & \\
\hline & $0.07 \% \mathrm{Na}_{2} \mathrm{EDTA}$ & & & & \\
\hline
\end{tabular}

${ }^{a}$ Only needed for the differentiation of Tilia species. 
Table 3 Inheritance analysis of $A p-A, A p-D$ and $F d h-A$ in T. cordata



NA: not applicable. $N$ is the sample size, a refers to the test of the hypothesis $N_{i j}=N_{i i}+N_{j j}$, and b to the test of the hypothesis $N_{i k}=N_{j k}(k \neq i, j)$.

Table 4 Inheritance analysis of $M d h-D, M n r-A, P g i-B$ and Pgi-C in T. cordata

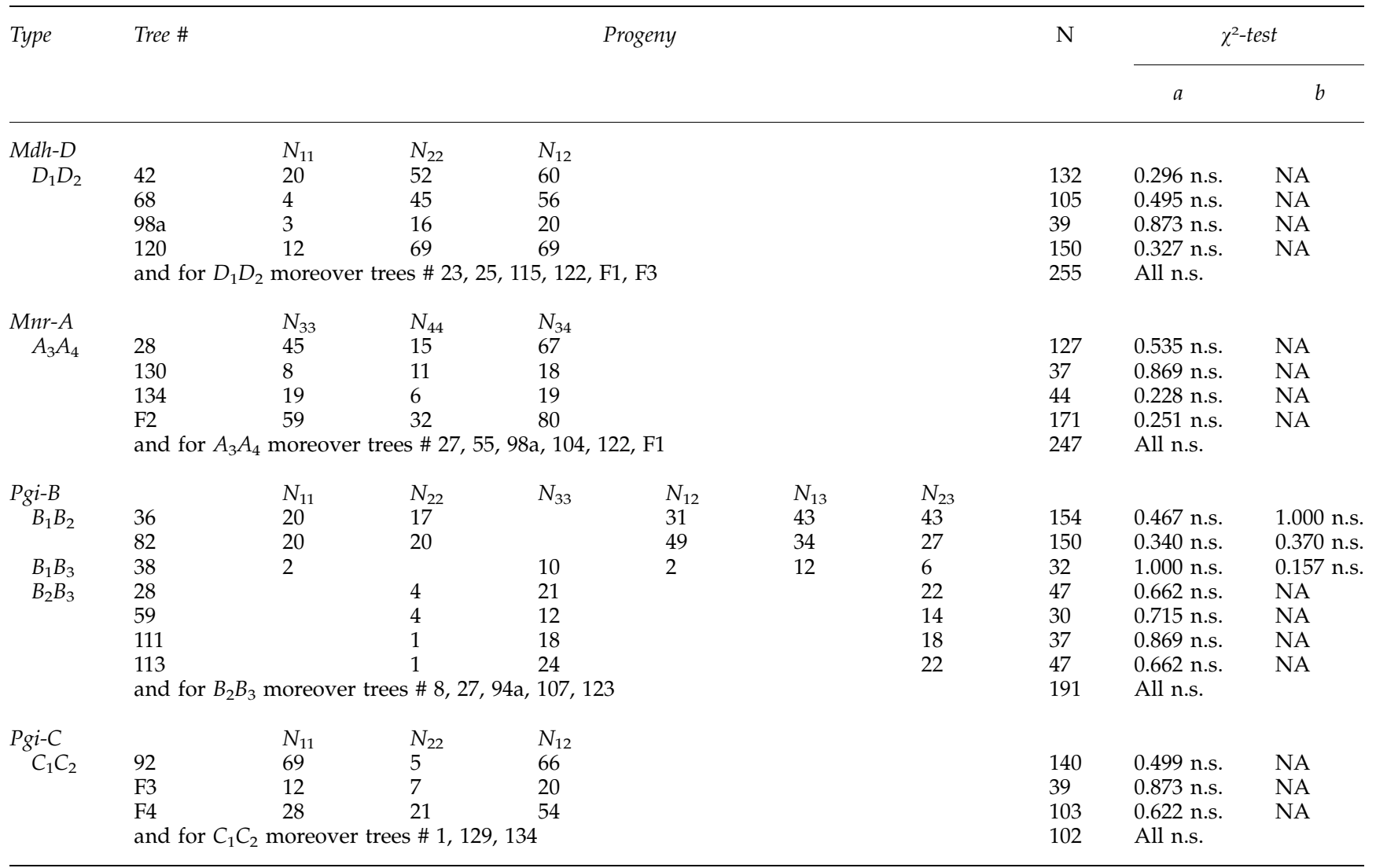

NA: not applicable. $N$ is the sample size, a refers to the test of the hypothesis $N_{i j}=N_{i i}+N_{j j}$, and $\mathrm{b}$ to the test of the hypothesis $N_{i k}=N_{j k}(k \neq i, j)$. 
Table 5 Inheritance analysis of $P g m-A, P g m-B, P g m-C$ and $P g m-D$ in T. cordata

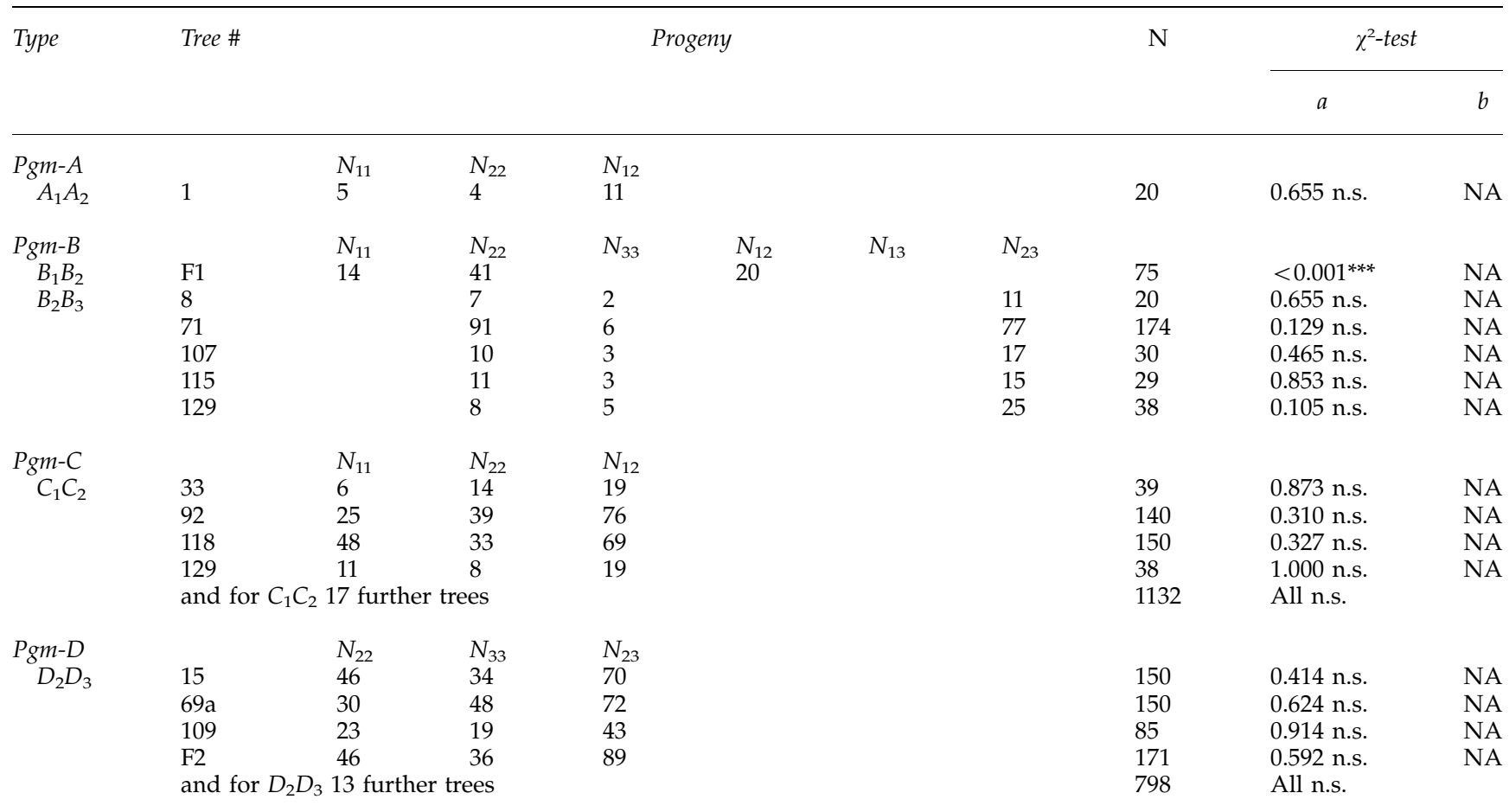

NA: not applicable. $N$ is the sample size, a refers to the test of the hypothesis $N_{i j}=N_{i i}+N_{j j}$, and $\mathrm{b}$ to the test of the hypothesis $N_{i k}=N_{j k}(k \neq i, j)$.

Table 6 Inheritance analysis of $S k d h-B$ in T. cordata

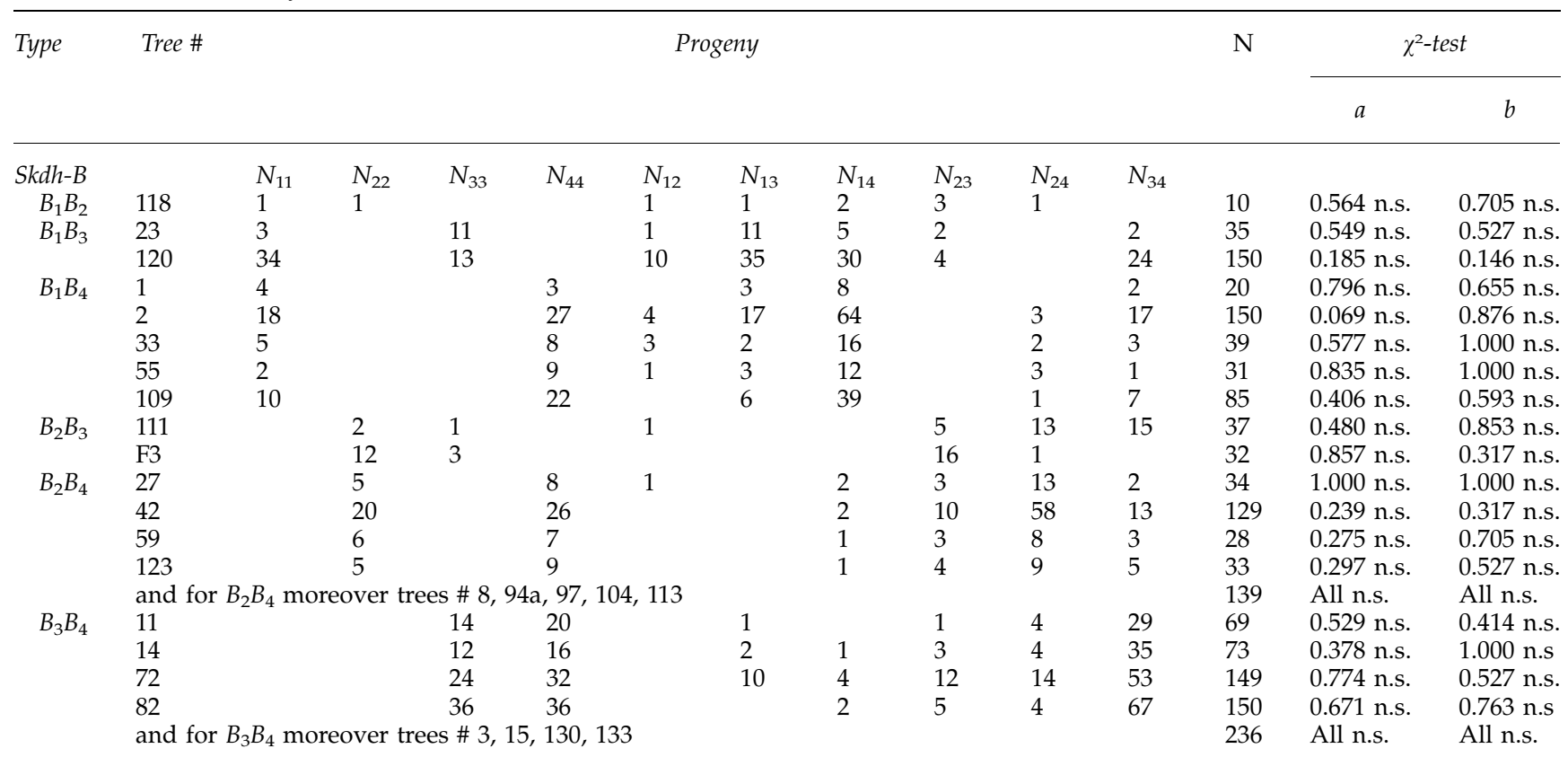

$N$ is the sample size, a refers to the test of the hypothesis $N_{i j}=N_{i i}+N_{j j}$, and b to the test of the hypothesis $N_{i k}=N_{j k}(k \neq i, j)$.

which made definite identification of the allozymes difficult (Figure 1). In T. cordata, variants at locus $A p-D$ could only be separated using histidine-citrate system; with the Ashton and Braden (1961) system this locus appeared monomorphic.
For $A p-B$, four enzyme variants were found, none of which was specific for any of the Tilia species. Likewise, locus $A p-D$ has four variants, while variants $A p-D_{1}$ and $A p-D_{2}$ were observed in T. cordata, and variants $A p-D_{3}$ and $A p-D_{4}$ occurred only in T. platyphyllos. For hybrids of 

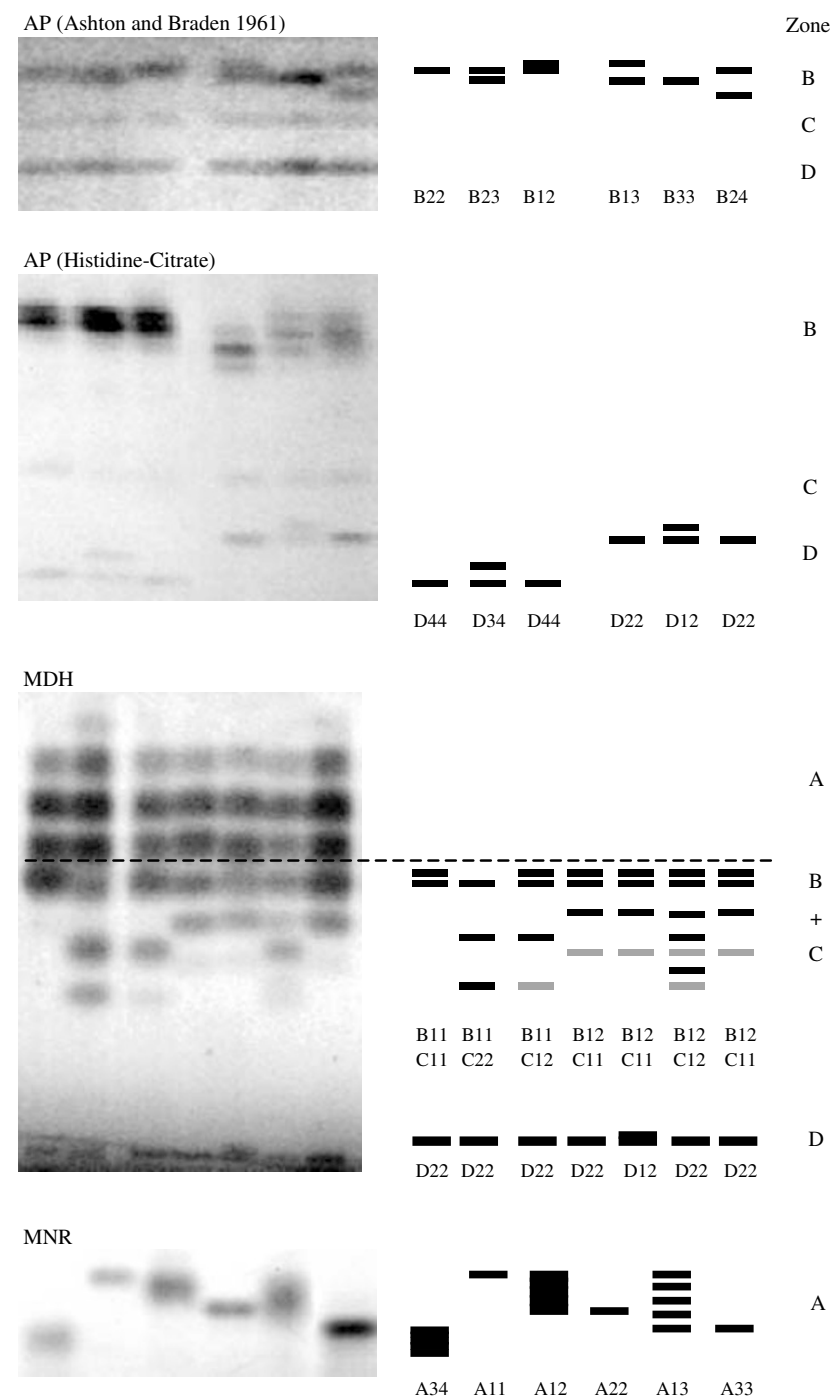

Figure 1 Zymograms of Tilia for the enzyme systems AP, MDH and MNR, with schematic illustrations and genotype designation. Genotypes, $A p-D_{3} D_{4}, A p-D_{4} D_{4}, M n r-A_{1} A_{1}, M n r-A_{1} A_{2}$ and $M n r-$ $A_{2} A_{2}$ are from T. platyphyllos; genotype $M n r-A_{1} A_{3}$ is T. cordata $\times T$. platyphyllos hybrid; all others are $T$. cordata.

T. cordata and T. platyphyllos, both of these speciesspecific enzyme variants were found. All segregation data were fully compatible with their expectations (Table 3).

\section{$\mathrm{MDH}$ - malate dehydrogenase}

There are at least four loci for the dimeric enzyme MDH in Tilia. Zone A (above the dashed line in Figure 1) showed no variation, although there appeared to be at least two gene loci which formed heterodimers. Inheritance analyses were successful only for locus $M d h-D$, because the loci in zones $M d h-B$ and $M d h-C$ overlap, and the alleles $M d h-B_{1}$ and $M d h-C_{1}$ have almost identical positions on the zymograms. Differentiation between the genotypes $M d h-B_{1} B_{2}$ and $M d h-B_{2} B_{2}, M d h-C_{1} C_{2}$ and $M d h-$ $C_{2} C_{2}$, respectively, was only possible through interpretation of slight differences in band staining intensity (lane 2 for $C_{2} C_{2}$ and lane 3 for $C_{1} C_{2}$ in Figure 1). Such differences
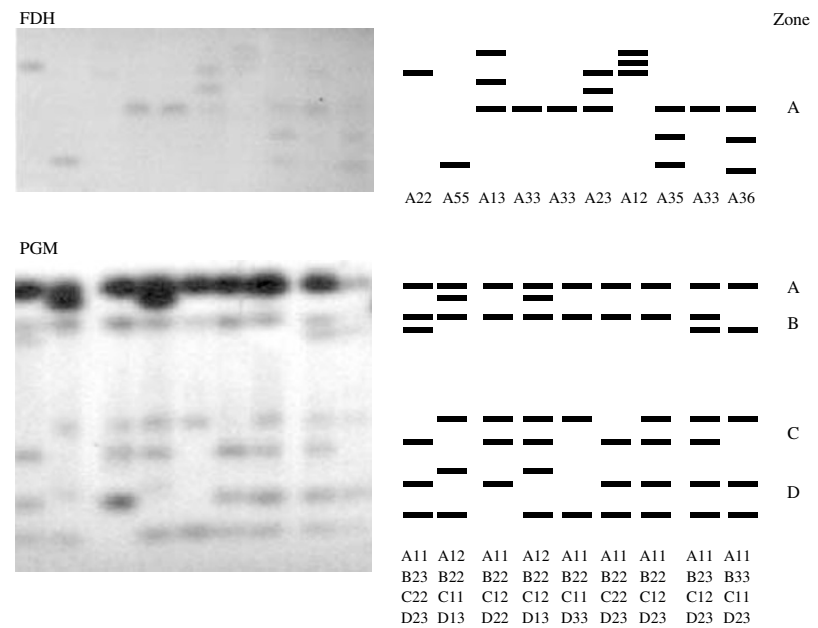

Figure 2 Zymograms of Tilia for the enzyme systems FDH and PGM with schematic illustrations and genotype designation. At the gene locus $F d h-A$, genotypes $A_{1} A_{1}$ and $A_{1} A_{2}$ are T. platyphyllos, while $A_{1} A_{3}$ and $A_{2} A_{3}$ denote T. cordata $\times$ T. platyphyllos hybrids. At the gene locus $P g m-D$, all genotypes containing $D_{1}$ are $T$. cordata $\times T$. platyphyllos hybrids. All other zymograms show T. cordata.

were too small for a reliable discrimination, especially in the seeds. Despite the missing inheritance analyses, a preliminary nomenclature for loci $M d h-B$ and $M d h-C$ is presented in Figure 1. The zymograms of adult trees could sometimes be interpreted if zymograms of their seeds were also available. For all three loci, only two variants were observed per locus, and there were no species-specific variants. All segregation data were fully compatible with their expectations (Table 4).

\section{MNR - menadione reductase}

For the tetrameric enzyme MNR, one zone of activity with four enzyme variants was visible (Figure 1). Allozymes $M n r-A_{3}$ and $M n r-A_{4}$ are T. cordata-specific and $M n r-A_{1}$ and $M n r-A_{2}$ are T. platyphyllos-specific; therefore $M n r-A_{1} A_{3}$ is a T. cordata $\times$ T. platyphyllos hybrid genotype. All segregation data were fully compatible with their expectations (Table 4).

\section{$\mathrm{FDH}$ - formate dehydrogenase}

One zone of weak activity was obtained for the dimeric enzyme FDH, for which six enzyme variants were detected (Figure 2). For genetic interpretation, the variants $F d h-A_{5}$ and $F d h-A_{6}$ were pooled, since differentiation of these allozymes was not possible in all cases.

The variants $F d h-A_{5}$ and $F d h-A_{6}$ were $T$. cordataspecific, variants $F d h-A_{1}, F d h-A_{2}$ and $F d h-A_{4}$ were T. platyphyllos-specific, while variant $F d h-A_{3}$ occurred in both species. All segregation data were fully compatible with their expectations (Table 3 ).

\section{PGM - phosphoglucomutase}

In $T$. cordata, four loci coding for the monomeric enzyme PGM were analysed (Figure 2). The zones Pgm- $A$ and $P g m-C$ showed two variants, while zones $P g m-B$ and $P g m-D$ had three enzyme variants. Variant $P g m-D_{1}$ is T. platyphyllos-specific. PGM zymograms of T. platyphyllos show complex banding patterns that were very different from those of T. cordata. Apart from variant $P g m-D_{1}$, an 
identification of other T. platyphyllos-specific variants was not possible; for this, inheritance analyses for T. platyphyllos were needed.

With one exception, segregation results (Table 5) of all zones were compatible with their expectations; among the progenies of tree $\mathrm{F} 1$ with genotype $B_{1} B_{2}$, by far too many homozygotes $B_{2} B_{2}$ were observed in comparison to heterozygotes $B_{1} B_{2}$. The highly significant deviation between the observed and expected frequencies in the progeny of this tree F1 seems to be caused by the variant $P g m-B_{1}$, since the inheritance mode for the allele $P g m-B_{2}$ is supported by the findings in several other single tree progenies. One of the above-mentioned assumptions must be violated and, therefore, the existence of the allele $P g m-B_{1}$ has to questioned until it is clarified by further investigations.

\section{$\mathrm{PGI}$ - phosphoglucose isomerase}

Zone A of the dimeric enzyme PGI showed variation, but because of the blurred patterns the locus could not be analysed. However, the patterns of loci Pgi-B and Pgi-C were clear and could be analysed by using the heterodimers as visual keys. A double band in zone $C$ indicates the presence of $C_{2}$. This interpretation is supported by an additional band in the heterodimer region of loci Pgi- $B$ and Pgi-C. Three allozymes at locus Pgi-B and two allozymes at $P g i-C$ were found in T. cordata. The enzyme variants of $T$. platyphyllos were different and no preliminary nomenclature of zones and alleles was possible. All segregation data were fully compatible with their expectations (Table 4).

\section{SKDH - shikimate dehydrogenase}

Zone $\mathrm{A}$ of the monomeric enzyme SKDH was variable but could not be resolved. However, zone $A$ was useful for discriminating both Tilia species. Locus $S k d h-B$ shows variation for seven allozymes, of which $S k d h-B_{1}-S k d h-B_{4}$ are T. cordata-specific and variants $S k d h-B_{5}-S k d h-B_{7}$ are T. platyphyllos-specific (genotypes $B_{4} B_{7}$ and $B_{1} B_{6}$ in Figure 3 are T. $\times$ europaea). Locus $S k d h-B$ was difficult to interpret since homozygote variants appear as double bands, and in heterozygotes, three or four bands were visible depending on allele migration. Additional difficulties were caused by differing staining intensities of the double bands for leaf and seed material. In leaf material, the intensity of the lower band was highest, while for seeds it was reversed. Segregations of all genotypes carrying alleles $B_{1}-B_{4}$ were fully compatible with their expected frequencies.

$\mathrm{IDH}$ - isocitrate dehydrogenase-and ACO-aconitase No inheritance analyses were carried out for these enzyme systems, although species-specific bands could still be utilized to distinguish $T$. cordata, T. platyphyllos and their hybrid.

\section{Discussion}

Species of the genus Tilia possess a chromosome set of either $n=6 \times=41$ or $n=12 \times=82$ (Seitz, 1951; Darlington and Wylie, 1955). T. cordata is assumed to be an allohexaploid and to originate through hybridization of an allotetraploid and a diploid species. The phenotypic expression of the enzymes corresponds to the banding

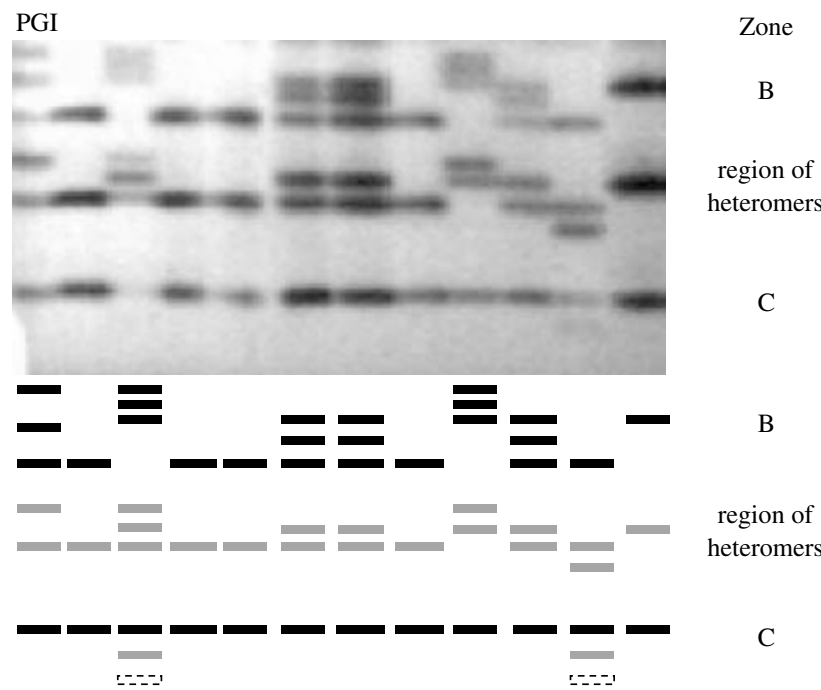

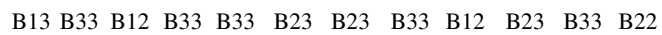
$\begin{array}{llllllllll}\text { C11 C11 C12 } & \text { C11 } & \text { C11 } & \text { C11 } & \text { C11 } & \text { C11 } & \text { C11 } & \text { C11 } & \text { C12 } & \text { C11 }\end{array}$

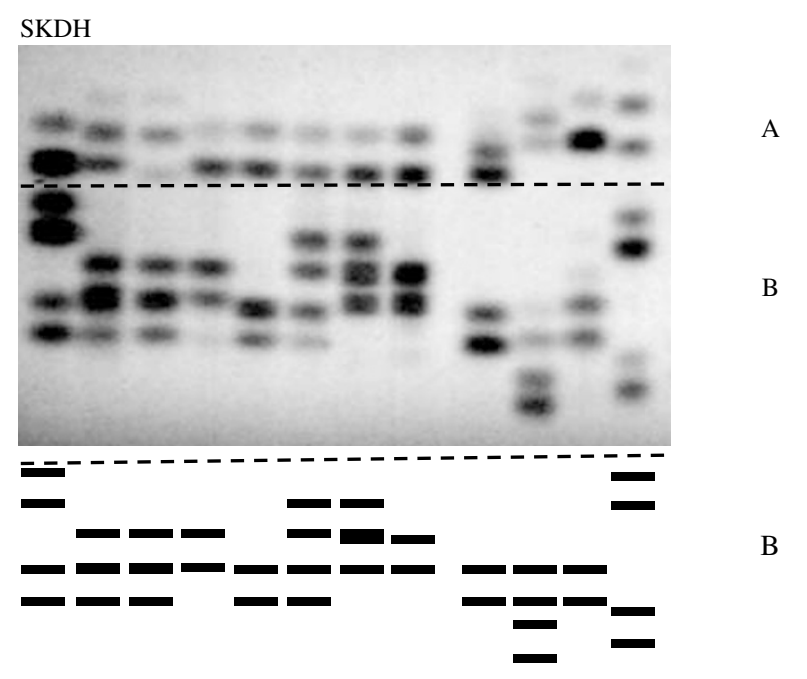

В14 В34 В34 В33 В44 В24 В23 B33 В44 B47 В44 В16

Figure 3 Zymograms of Tilia for the enzyme systems PGI and SKDH with schematic illustrations and genotype designation. For PGI, only T. cordata zymograms are shown. At the gene locus $S k d h-$ $B$, genotypes $B_{4} B_{7}$ and $B_{1} B_{6}$ are T. cordata $\times$ T. platyphyllos hybrids. Note that SKDH zymograms contain only double bands.

patterns of diploid organisms; homozygotes have one band for monomeric and multimeric enzyme systems, while for heterozygotes, there are two bands for monomeric enzymes, three for dimeric and five for tetrameric enzymes. In spite of being polyploid, T. cordata had disomic inheritance, just as tetraploid Acer pseudoplatanus (Konnert et al, 2001). In Tilia, for example, for PGI and PGM, allopolyploidy is not expressed as greater numbers of intralocus bands but as an increased number of loci compared to diploid organisms, for example, Fagus sylvatica (Müller-Starck and Starke, 1993), Quercus robur (Zanetto et al, 1996), Q. petraea. (Müller-Starck et al, 1996) and Acer campestre (Leinemann and Bendixen, 1999).

No cytological observations of meiosis were made, and as the phenotypes and their frequencies in single tree progenies were compatible with disomic inheritance, 
only tests based on the expectations of disomic segregation were made (Gillet and Hattemer, 1989). In case of autopolyploidy, the corresponding expectations were very different from those under disomic segregation, as shown for autotetraploid Prunus spinosa (Leinemann, 2000). Disomic segregation in T. cordata was of confirmed through statistical tests for almost all investigated loci and enzyme variants.

SKDH zymograms for homozygotes have only double bands. Corresponding findings have been made in other enzyme systems in forest trees: Bergmann (1974) found that two alleles at the gene locus coding for acid phosphatases in dormant seeds of Picea abies produce single bands while the other two alleles produce double bands even in haploid megagametophyte tissue. This author reports something similar on the gene locus Lap-A. In Fagus sylvatica double bands occur at Aat-B (aspartate aminotransferase, EC 2.6.1.1; Müller-Starck et al, 2001), and in Abies alba at Idh-A (Hussendörfer et al, 1995). It is unknown whether the two bands visible in vitro possess markedly different structure or whether they are only modified during electrophoresis.

T. platyphyllos genotypes were only inferred from the T. cordata results. Zymograms of T. platyphyllos showed different banding patterns indicating specific alleles at several gene loci. Since the two species also have alleles in common, the (minimum) proportion of hybrid $\mathrm{F}_{1}$ seeds among the progeny of T. cordata in the Schwiegershausen forest can only be detected by considering all gene loci (Fromm, 1999). Although the differentiation of tree populations of the same species at allozyme gene loci is generally low and private alleles have rarely been found (Loveless, 1992; Müller-Starck et al, 1992), only more extensive surveys will confirm the species specificity of the alleles.

The high proportion of species-specific enzyme variants in both Tilia species leads to the assumption that interspecific hybridization and introgression are restricted. Introgression between the two Tilia species appears to take place only to a minor degree, in contrast to the genus Quercus (Rushton, 1993; Bacilieri et al, 1996; Finkeldey, 2001).

Restricted introgression may have several reasons. Different growing site demands for $T$. cordata and T. platyphyllos mean that the species are sympatric only at a few sites. Additionally, mating between the two species is restricted by different flowering periods; the flowering period of $T$. platyphyllos generally starts 2 weeks earlier than that of $T$. cordata. Furthermore, introgression of the two Tilia species is hindered through the low production of fertile seeds produced by the few hybrids. The fruit appendage of the hybrids is often large but most of the fruits contain only empty seeds (Scheller, 1972; Fromm, 2001). On the other side, the flowering periods of $T$. cordata and the hybrids overlap (Pigott, 1991; Fromm, 2001) and 20 of the 3864 fertile seeds collected from $T$. cordata in the Schwiegershausen forest carried T. platyphyllos-specific alleles and were inferred to be the result of fertilization by one of the three hybrids in the population. In the Schwiegershausen population, hybrid pollen were as successful as T. cordata pollen in fertilizing $T$. cordata ovules (Fromm, 2001). The 20 seeds were not included in segregation analyses. It is not known if these seeds are as viable as pure T. cordata seeds in later ontogenetic stages.

\section{Acknowledgements}

This research was supported by a grant from Deutsche Forschungsgemeinschaft. The authors are greatly obliged to two anonymous reviewers for their helpful comments.

\section{References}

Ashton GC, Braden AWH (1961). Serum $\beta$-globulin polymorphism in mice. Austr J Biol Sci 14: 248-253.

Bacilieri R, Ducousso A, Petit R, Kremer A (1996). Mating system and asymmetric hybridisation in a mixed stand of European oaks. Evolution 50: 900-908.

Bergmann F (1974). The genetics of some allozyme systems in spruce endosperm (Picea abies). Genetika 6: 353-360.

Darlington CD, Wylie AP (1955). Chromosome Atlas of Flowering Plants. George Allen and Unwin Ltd: London.

Fineschi S, Gillet E, Malvolti E (1989). Genetics of sweet chestnut (Castanea sativa Mill.). III. Genetic analysis of zymograms of single tree offspring. Silvae Genet 39: 188-194.

Finkeldey R. (2001). Genetic variation of oaks (Quercus spp.) in Switzerland. 2. Genetic structures on pure and mixed forests of pedunculate oak (Quercus robur L.) and sessile oak (Q. petraea (Matt.) Liebl.). Silvae Genet 50: 22-30.

Fromm M (1999). Artbestimmung von Winterlinde, Sommerlinde und der Arthybride. AFZ/Der Wald 5: 244-246.

Fromm M (2001). Reproduktion einer entomophilen Baumart in geringer Populationsdichte-Das Beispiel der Winterlinde (Tilia cordata Mill.). PhD Thesis, Universtität Göttingen, 239pp. http:/ / webdoc.sub.gwdg.de/diss/2001/fromm/index.html

Gillet E, Hattemer HH (1989). Genetic analysis of isoenzyme phenotypes using single tree progenies. Heredity 63: 135-141.

Hussendörfer E, Konnert M, Bergmann F (1995). Inheritance and linkage of isozyme variants of silver fir (Abies alba Mill.). For Genet 2: 29-40.

Keiper J (1916). Die Linde im Pfälzerwald und in den übrigen Waldgebieten der Pfalz. Forstwiss Centralbl 38: 223-369.

Konnert M, Ruetz W, Fromm M (2001). Genetic variation in Acer pseudoplatanus L. I. Inheritance of allozyme variants. For Genet 8: 25-37.

Leinemann L (2000). Inheritance analysis of allozyme phenotypes in tetraploid species using single plant progenies. An example in black thorn (Prunus spinosa L.). For Genet 7: 205209.

Leinemann L, Bendixen K (1999). Inheritance of allozyme variants in field maple (Acer campestre L.). For Genet 6: 73-79.

Loveless MD (1992). Isozyme variation in tropical trees: patterns of genetic organization. New Forests 6: 67-94.

Maurer WD, Tabel U (1995). A methodical study to improve the allozyme analysis for identification of clones of Tilia. Silvae Genet 44: 351-356.

Müller-Starck G, Baradat PH, Bergmann F (1992). Genetic variation within European tree species. New Forests 6 : 23-47.

Müller-Starck G, Konnert M, von Wühlisch G (2001). Labormanual zur Durchführung von Isoenzymanalysen bei der Buche (Fagus sylvatica L.). Freising, Bund-Länder Arbeitsgemeinschaft 'Forstliche Genressourcen und Forstsaatgutrecht'. http:/ / www.ncbi.nlm.nih.gov.

Müller-Starck G, Starke R (1993). Inheritance of isoenzymes in European beech (Fagus sylvatica L.). J Hered 84: 291-296.

Müller-Starck G, Zanetto A, Kremer A, Herzog S (1996). Inheritance of isozymes in the genus Quercus: II. Sessile oak (Quercus petrea (Matt.) Liebl.) and offspring from interspecific crosses. For Genet 3: 1-12.

Murillo O, Hattemer HH (1997). Inheritance of allozyme variants of Alnus acuminata ssp. arguta (Schlectendal) Furlow. Silvae Genet 46: 51-55. 
Papageorgiou AC, Bergmann F, Gillet E, Hattemer HH (1993). Genetic analysis of isoenzyme variation in Mediterranean cypress (Cupressus sempervirens L.). Silvae Genet 42: 109-111.

Pigott CD (1991). Biological flora of the British Isles. Tilia cordata Miller. J Eco 79: 1147-1207.

Rushton BS (1993). Natural hybridisation within the genus Quercus L. Ann Sci For 50: 73-90.
Scheller H (1972). Die Linden in Gärten und Parks des unteren Maingebietes. Mitt Dtsch Dendrol Ges 65: 7-42.

Seitz FW (1951). Chromosomenzahlverhältnisse bei Holzpflanzen. Z Forstgenetik 1: 22-32.

Zanetto A, Kremer A, Müller-Starck G, Hattemer HH (1996) Inheritance of isozymes in pedunculate oak (Quercus robur L.). Heredity 87: 364-370. 